\title{
SEASONALITY IN TOURIST EMPLOYMENT AND EARNINGS
}

\author{
Ronald R. Schultz and William B. Stronge*
}

Visitors provide economic benefits to the residents of a region in a variety of ways. Chief among these are the employment opportunities created for those who supply them with goods and services, and the increased income generated by the expenditures of such employees. Employment created by visitors, however, is usually subject to seasonal fluctuations, and these fluctuations may reduce the net social return from public expenditures that promote and encourage the tourist industry. Thus, it is important to measure and analyze the impact of seasonality on tourist employment and earnings.

The conventional analysis of the impact of seasonality on tourist employment and earnings is described in Chiswick [2, pp. 15-16]. The decline in the demand for labor during the off-season is regarded as an undesirable feature of a tourist related job, and a compensating wage differential is accordingly needed to attract workers into tourist occupations. Such analysis assumes that there are no corresponding seasonal fluctuations in the supply of labor. To the extent that individuals reduce their supply of labor during the off-season, however, the seasonal layoffs might be regarded as desirable, and the need for a compensating differential correspondingly reduced.

In regions where the tourist season occurs in the summer, large numbers of high school and college students may be hired, and the decline in labor demand at the end of the summer is to some degree matched by a decline in labor supply. In winter tourism regions, off-seasonal declines in labor supply may not occur. The complementarity of the school and tourist seasons in summer regions is not present in winter regions. On the other hand, the labor supply of two nonstudent groups may decline during the summer, namely, parents of school age children and those with strong preferences for outdoor recreation. Thus, even in winter tourist regions some decline in labor supply may occur.

This paper provides an analysis of the effect of seasonality on hotel and restaurant employees in southeast Florida. Section one gives a brief outline of the design of the study. The second section summarizes the seasonal fluctuations in employment, hours worked, and earnings per hour experienced by those in the occupations studied. A third section extends the results to allow for seasonal labor supply as well as demand shifts. The paper concludes with some implications for public policy.

\footnotetext{
* Associate Professor of Geography and Associate Professor of Economics, respectively, Florida Atlantic University, Boca Raton, Florida 33431
} 


\section{DESIGN OF THE STUDY}

This study is based on a survey of employees in hotels and restaurants in southeast Florida. The state had over 32 million out of state visitors in 1978 [6], and its economy is among the most dependent on tourism in the nation [3]. Much of the state's tourist industry is located in the southeast corner, although central Florida's share has been growing due primarily to Disney World. The most seasonal component of the state's tourist industry is in the southeast [8 pp. 14-19], so this area was an appropriate setting for the study. In addition, southeast Florida is composed of three adjacent SMSA's with a population of three million, thus a considerable amount of secondary data was available.

Data were collected on the front line tourist industries: hotels, motels, and restaurants. Because of the licensing requirements of state law, a sampling frame of establishments with data on capacity and size was readily available. [4] Questionnaires were obtained from 442 employees during the winter season. Further details on methodology and response rates are available in [8].

The questionnaire obtained information on the employee's age, race, formal education, sex, and marital status as basic information for a demographic profile. A second set of questions sought data on occupation of respondent and spouse; the length of time respondent expected to be so employed in South Florida during 1978; the number of hours worked per week in the winter tourist season; and respondent's attitude toward the seasonal nature of the tourist industry.

The third section of the questionnaire dealt with expected employment and earnings during the off-season. Employees were asked if they expected to be in South Florida during the slow season, and if so, what occupation would they have, how many hours per week would they work, and how would their earnings be affected. These three sets of questions captured the basic information needed to examine the impact of seasonality on the employees of the tourist industry while not adversely affecting response rates due to length of the questionnaire or complexity of the questions. The information provided by the sampled employees was blown up to represent total employees in each industry by weighting each questionnaire with its share of the population in the occupation. Totals for each occupation were obtained from a sample of employers and by using the room and seating capacity data from state files $[8, \mathrm{pp}$. 41-54].

\section{THE IMPACT OF SEASONALITY ON THE NUMBER OF JOBS}

The significance of seasonal fluctuations for employment in hotels, motels, and restaurants is illustrated by data from the Florida Department of Labor which show that from 1973 through 1977 hotel employment in Miami in February averaged 14.5 percent above the annual average while it was 13.1 percent below the annual average in September [5]. 
Comparisons between employees' season and expected off-season occupations are given in Tables 1, 2, and 3. Four possibilities were distinguished: An employee might (1) remain in the same occupation, (2) leave the labor force altogether, (3) move to a higher status occupation, (4) or move to a lower status occupation. Employees who moved to higher status occupations typically represented students, apprentices, and other such individuals who were expecting to graduate and to enter a higher level occupation as a result. The major changes due to seasonal fluctuations could be expected to be found among those dropping out of the labor force or those moving to lower occupations.

No survey data on unemployment was included in the analysis for two reasons. An unemployed person is defined as one who is seeking a job. Since the questionnaire was administered during the winter season employees could be divided into those who intended to work during the off-season and those who did not. The latter expected to leave the labor force, and we had no way of predicting the success rate (employment rate) among the former. Secondly, those employees in the tourist industry who intended to collect unemployment compensation during the off-season would be reluctant to admit this on a questionnaire.

Over three-fourths of all employees expected to remain in the same occupation in the off-season as they were in during the season (Table 1). About one out of every seven employees expected to drop out of the labor force completely and one in fourteen employees expected to move to a better occupation in terms of socioeconomic status, as measured by Duncan's index [7, pp. 319-329]. The percentage of employees who expected to change to an occupation with lesser status was negligible (1.5 percent).

The percentages of food service employees (Table 2) and hotel-motel nonfood employees (Table 3 ) who expected to remain employed in the same oc-

TABLE 1

Comparison of Off-Season with Season Occupations for Hotel and Restaurant Employees

\begin{tabular}{|c|c|c|c|c|c|c|}
\hline & \multicolumn{2}{|c|}{$\begin{array}{c}\text { Food Service } \\
\text { Employees }\end{array}$} & \multicolumn{2}{|c|}{$\begin{array}{c}\text { Hotel and Motel } \\
\text { Non-Food Service } \\
\text { Employees }\end{array}$} & \multicolumn{2}{|c|}{ All Employees } \\
\hline & \# & $\%$ & $\#$ & $\%$ & $\#$ & $\%$ \\
\hline Same Occupation & 59,717 & 76.9 & 20,209 & 77.6 & 79,926 & 77.1 \\
\hline Out-of-Labor Force & 10,369 & 13.4 & 4,183 & 16.1 & 14,552 & 14.0 \\
\hline Better Occupations ${ }^{\mathrm{a}}$ & 6,446 & 8.3 & 1,209 & 4.6 & 7,655 & 7.4 \\
\hline Lower Occupations ${ }^{\text {a }}$ & 1,133 & 1.5 & 459 & 1.8 & 1,592 & 1.5 \\
\hline Total $^{b}$ & 77,665 & 100.0 & 26,060 & 100.0 & 103,725 & 100.0 \\
\hline
\end{tabular}

\footnotetext{
aAs determined by Duncan's index of socioeconomic status

hIndividual items may not add to total because of rounding.
} 
cupation were about the same. A greater proportion of hotel employees who expected to leave their occupation in the off-season intended to drop out of the labor force; a greater proportion of those in the food service industry expected to move to better occupations. This would be consistent with a tendency for students to be employed seasonally in food service and housewives to be employed seasonally in hotels-motels.

Among food service occupations bartenders, waiters/waitresses, and cooks contained relatively many individuals who retain the same occupation in the off-season, whereas cashiers (clerical), cleaners, parking attendants, kitchen help, and entertainers contain relatively few individuals who remain in the

\section{TABLE 2}

Comparison of Off-Season with Season Occupations for Food Service Employees by Seasonal Occupation

\begin{tabular}{|c|c|c|c|c|}
\hline & $\begin{array}{c}\text { Same } \\
\text { Occupation }\end{array}$ & $\begin{array}{c}\text { Out of } \\
\text { Labor Force }\end{array}$ & $\begin{array}{c}\text { Better } \\
\text { Occupations }{ }^{\mathrm{a}}\end{array}$ & $\begin{array}{c}\text { Lower } \\
\text { Occupations }\end{array}$ \\
\hline \multicolumn{5}{|l|}{ Clerical } \\
\hline Number & 3,657 & 563 & 281 & 844 \\
\hline Percentage & 68.4 & 10.5 & 5.3 & 15.8 \\
\hline \multicolumn{5}{|l|}{ Cleaners } \\
\hline Number & 0 & 775 & 0 & U \\
\hline Percentage & 0 & 100.0 & 0 & 0 \\
\hline \multicolumn{5}{|c|}{ Parking Attendants } \\
\hline Number & 216 & 216 & 216 & 0 \\
\hline Percentage & 33.3 & 33.3 & 33.3 & 0 \\
\hline \multicolumn{5}{|l|}{ Bartenders } \\
\hline Number & 2,982 & 271 & 0 & 0 \\
\hline Percentage & 91.7 & 8.3 & 0 & 0 \\
\hline \multicolumn{5}{|c|}{ Waiters/Waitresses } \\
\hline Number & 26,692 & 1,639 & 2,576 & 0 \\
\hline Percentage & 86.4 & 5.3 & 8.3 & 0 \\
\hline \multicolumn{5}{|c|}{ Busboys/Busgirls } \\
\hline Number & 7,526 & 2,026 & 1,158 & 289 \\
\hline Percentage & 68.4 & 18.4 & 10.5 & 2.6 \\
\hline \multicolumn{5}{|l|}{ Cooks } \\
\hline Number & 11,611 & 860 & 0 & 0 \\
\hline Percentage & 93.1 & 6.9 & 0 & 0 \\
\hline \multicolumn{5}{|l|}{ Kitchen Help } \\
\hline Number & 6,646 & 2,215 & 2,215 & 0 \\
\hline Percentage & 60.0 & 20.0 & 20.0 & 0 \\
\hline \multicolumn{5}{|l|}{ Entertainers } \\
\hline Number & 387 & 1,937 & 0 & 0 \\
\hline Percentage & 16.7 & 83.3 & 0 & 0 \\
\hline \multicolumn{5}{|c|}{ All Food Service } \\
\hline \multicolumn{5}{|c|}{ Employees } \\
\hline Number & 59,717 & 10,369 & 6,446 & 1,133 \\
\hline Percentage & 76.9 & 13.4 & 8.3 & 1.5 \\
\hline
\end{tabular}

\footnotetext{
aAs determined by Duncan's index of socioeconomic status
} 
TABLE 3

Comparison of Off-Season with Season Occupations for Non-Food Service Hotel Employees by Seasonal Occupation

\begin{tabular}{|c|c|c|c|c|}
\hline & $\begin{array}{c}\text { Same } \\
\text { Occupation }\end{array}$ & $\begin{array}{c}\text { Out of } \\
\text { Labor Force }\end{array}$ & $\begin{array}{c}\text { Better } \\
\text { Occupations }^{\mathrm{a}}\end{array}$ & $\begin{array}{c}\text { Lower } \\
\text { Occupations }^{\mathrm{a}}\end{array}$ \\
\hline \multicolumn{5}{|l|}{ Clerical } \\
\hline Number & 3,832 & 659 & 0 & 60 \\
\hline Percentage & 84.2 & 14.5 & 0 & 1.3 \\
\hline \multicolumn{5}{|l|}{ Bellhops } \\
\hline Number & 1,645 & 118 & 353 & 0 \\
\hline Percentage & 77.8 & 5.6 & 16.7 & 0 \\
\hline \multicolumn{5}{|l|}{ Maids } \\
\hline Number & 9,420 & 2,569 & 856 & 214 \\
\hline Percentage & 72.1 & 19.7 & 6.6 & 1.6 \\
\hline \multicolumn{5}{|c|}{ Parking Attendants } \\
\hline Number & 629 & 315 & 0 & 0 \\
\hline Percentage & 66.7 & 33.3 & 0 & 0 \\
\hline \multicolumn{5}{|l|}{ Managers } \\
\hline Number & 2,399 & 185 & 0 & 185 \\
\hline Percentage & 86.7 & 6.7 & 0 & 6.7 \\
\hline \multicolumn{5}{|l|}{ Bartenders } \\
\hline Number & 2,029 & 254 & 0 & 0 \\
\hline Percentage & 88.9 & 11.1 & 0 & 0 \\
\hline \multicolumn{5}{|l|}{ Other } \\
\hline Number & 254 & 85.0 & 0 & 0 \\
\hline Percentage & 75.0 & 25.0 & 0 & 0 \\
\hline \multicolumn{5}{|c|}{ All Non-Food Service } \\
\hline \multicolumn{5}{|c|}{ Employees } \\
\hline Number & 20,209 & 4,183 & 1,209 & 459 \\
\hline Percentage & 77.6 & 16.1 & 4.6 & 1.8 \\
\hline
\end{tabular}

as determined by Duncan's index of socioeconomic status

TABLE 4

Seasonal Changes in Average Weekly Hours

\begin{tabular}{lrrrr}
\hline & Decline & No Change & Increase & Total $^{\mathrm{a}}$ \\
\hline Food Service Occupations & & & & \\
$\quad$ Number & 20,494 & 25,513 & 3,981 & 49,991 \\
$\quad$ Percentage & 41.0 & 51.1 & 7.9 & 100.0 \\
$\begin{array}{l}\text { Non-Food Service Hotel } \\
\text { Occupations }\end{array}$ & & & & \\
$\quad$ Number & 8,546 & 8,611 & 120 & 17,277 \\
$\quad$ Percentage & 49.5 & 49.8 & 0.7 & 100.0 \\
Total & & & & \\
$\quad$ Number & 29,040 & 34,124 & 4,104 & 67,268 \\
$\quad$ Percentage & 43.2 & 50.7 & 6.1 & 100.0 \\
\hline
\end{tabular}

${ }^{a}$ Items may not add to total due to rounding. 
same occupation. An important source of these occupational differences may be the different proportions of females and students in them. Also, many of the occupations experiencing the greatest seasonal decline had relatively low socioeconomic ranking.

Results for the non-food service occupations in hotels and motels show that the categories of desk clerk, manager, and bartender contain relatively many individuals who expected to retain the same occupation in the off-season whereas the categories of maid and parking attendant contain relatively few such individuals. The higher status occupations again seem to experience less of a seasonal decline, and the relatively small percentage of those changing to better occupations indicates the presence of fewer students.

\section{SEASONAL FLUCTUATIONS IN HOURS WORKED}

A second type of seasonality of interest is fluctuation in hours worked. This is analyzed for those individuals who retain the same occupation in the offseason. The results are presented in Table 4. Forty-three percent of the employees in hotels, motels, and restaurants expected to experience a decline in hours worked during the off-season. About one in sixteen expected to experience an increase. The decline in hours is sharper in non-food service hotel occupations where one out of two employees experiences a reduction (Table 5 ). The percentage experiencing an increase in weekly hours in food service occupations is 7.9 (Table 6), whereas in hotels-motels it is only 0.7 percent. Nevertheless, the decline in hours worked is substantial in all food service occupations other than cooks.

The data in these two tables can be combined with the occupational comparison data in Tables 2 and 3 to yield a measure of the desirability of the occupations in motels, hotels, and restaurants to an individual seeking full-time, full year employment. The results are given in Table 7. They indicate that all cleaners, parking attendants, and almost all entertainers in food service establishments either change occupation or experience a reduction in hours. Cashiers, busboys, and kitchen help in food service establishments also experience considerable attrition or hours reduction. Maids, parking attendants, managers, and bartenders in hotels have a similar experience. Cooks and waiters/waitresses experience relatively less attrition and hours reduction. The same is true of the front desk staff in hotels.

\section{SEASONAL FLUCTUATIONS IN EARNINGS PER HOUR}

The third type of seasonal influence on hotel and restaurant occupations is seasonality in earnings. Insofar as employees experience a reduction in hours, their earnings can be expected to decline in the off-season, but they may also experience a decline in earnings per hour, particularly if they work in the tipping zone. Information on this aspect of hotel and restaurant employment is difficult to obtain. Survey respondents are usually reluctant to provide information on earnings. This is more true of employees in restaurants and hotels- 
TABLE 5

Seasonal Changes in Average Weekly Hours Worked by Non-Food Service Hotel Occupation

\begin{tabular}{|c|c|c|c|}
\hline & \multicolumn{3}{|c|}{ Change in Average Week ly Hours } \\
\hline & Decline & No Change & Increase \\
\hline \multicolumn{4}{|l|}{ Clerical } \\
\hline Number & 1,019 & 2,335 & 120 \\
\hline Percentage & 29.3 & 67.3 & 3.4 \\
\hline \multicolumn{4}{|l|}{ Bellhops } \\
\hline Number & 471 & 823 & 0 \\
\hline Percentage & 36.4 & 63.6 & 0 \\
\hline \multicolumn{4}{|l|}{ Maids } \\
\hline Number & 4,068 & 3,640 & 0 \\
\hline Percentage & 52.8 & 47.2 & 0 \\
\hline \multicolumn{4}{|c|}{ Parking Attendants } \\
\hline Number & 314 & 314 & 0 \\
\hline Percentage & 50.0 & 50.0 & 0 \\
\hline \multicolumn{4}{|l|}{ Managers } \\
\hline Number & 1,662 & 738 & 0 \\
\hline Percentage & 69.2 & 30.8 & 0 \\
\hline \multicolumn{4}{|l|}{ Bartenders } \\
\hline Number & 1,015 & 307 & 0 \\
\hline Percentage & 66.7 & 33.3 & 0 \\
\hline \multicolumn{4}{|l|}{ Other } \\
\hline Number & 0 & 254 & 0 \\
\hline Percentage & 0 & 100.0 & 0 \\
\hline \multicolumn{4}{|c|}{ All Non-Food Employees } \\
\hline Number & 8,546 & 8,611 & 120 \\
\hline Percentage & 49.5 & 49.8 & 0.7 \\
\hline
\end{tabular}

TABLE 6

Seasonal Changes in Average Weekly Hours Worked by Food Service Occupation

\begin{tabular}{|c|c|c|c|}
\hline & \multicolumn{3}{|c|}{ Change in Average Weekly Hours } \\
\hline & Decline & No Change & Increase \\
\hline \multicolumn{4}{|l|}{ Clerical } \\
\hline Number & 1,125 & 2,251 & 0 \\
\hline Percentage & 33.3 & 66.7 & 0 \\
\hline \multicolumn{4}{|c|}{ Parking Attendants } \\
\hline Number & 216 & 0 & 0 \\
\hline Percentage & 100.0 & 0 & 0 \\
\hline \multicolumn{4}{|l|}{ Bartenders } \\
\hline Number & 1,355 & 1,084 & 271 \\
\hline Percentage & 50.0 & 40.0 & 10.0 \\
\hline \multicolumn{4}{|c|}{ Waiters/Waitresses } \\
\hline Number & 10,537 & 11,239 & 1,405 \\
\hline Percentage & 45.5 & 48.4 & 6.1 \\
\hline \multicolumn{4}{|c|}{ Busboys/Busgirls } \\
\hline Number & 2,894 & 2,316 & 1,447 \\
\hline Percentage & 43.5 & 34.8 & 21.7 \\
\hline \multicolumn{4}{|l|}{ Cooks } \\
\hline Number & 2,150 & 6,020 & 860 \\
\hline Percentage & 23.9 & 66.7 & 9.5 \\
\hline \multicolumn{4}{|l|}{ Kitchen Help } \\
\hline Number & 2,215 & 2,215 & 0 \\
\hline Percentage & 50.0 & 50.0 & 0 \\
\hline \multicolumn{4}{|l|}{ Entertainers } \\
\hline Number & 0 & 387 & 0 \\
\hline Percentage & 0 & 100.0 & 0 \\
\hline \multicolumn{4}{|c|}{ All Food Service Employees } \\
\hline Number & 20,494 & 25,513 & 3,948 \\
\hline Percentage & 41.0 & 51.1 & 7.9 \\
\hline
\end{tabular}




\section{TABLE 7}

The Desirability of Hotel and Restaurant Occupations

to an Individual Desiring a Full-Time Full-Year Job

(Percent of Total Seasonal Employment)

\begin{tabular}{|c|c|c|c|c|c|}
\hline & $\begin{array}{c}\text { Decline in } \\
\text { Occupational } \\
\text { Membership } \\
\text { in Off-season }\end{array}$ & $\begin{array}{l}\text { Decline in } \\
\text { Average } \\
\text { Weekly Hours } \\
\text { in Off-season }\end{array}$ & $\begin{array}{c}\text { Decline in } \\
\text { Occupational } \\
\text { Membership or } \\
\text { Weekly Hours }\end{array}$ & $\begin{array}{l}\text { Full-Time } \\
\text { Full-Year } \\
\text { Employment }\end{array}$ & \\
\hline \multicolumn{6}{|l|}{ FOOD SER VICE } \\
\hline Clerical/cashiers & 31.6 & 21.0 & 52.6 & 47.4 & \\
\hline Cleaners & 100.0 & 0.0 & 100.0 & 0.0 & \\
\hline Parking Attendants & 67.7 & 33.3 & 100.0 & 0.0 & \\
\hline Bartenders & 8.3 & 41.7 & 50.0 & 50.0 & \\
\hline Waiters/Waitresses & 13.6 & 34.1 & 47.7 & 52.3 & \\
\hline Busboys/Busgirls & 31.6 & 26.3 & 57.9 & 42.1 & \\
\hline Cooks & 6.9 & 17.2 & 24.1 & 75.9 & \\
\hline Kitchen Help & 40.0 & 20.0 & 60.0 & 40.0 & \\
\hline Entertainers & 83.3 & 0.0 & 83.0 & 17.0 & \\
\hline TOTAL & 23.1 & 26.3 & 49.4 & 50.6 & \\
\hline \multicolumn{6}{|l|}{ NON-FOOD SER VICE HOTEL } \\
\hline Clerical/cashiers & 15.8 & 22.4 & 38.2 & 61.8 & \\
\hline Bellhops & 22.2 & 22.3 & 44.5 & 55.5 & \\
\hline Maids & 27.9 & 31.1 & 59.0 & 41.0 & \\
\hline Parking Attendants & 33.3 & 33.3 & 66.6 & 33.4 & \\
\hline Managers & 13.3 & 60.0 & 73.3 & 26.7 & \\
\hline Bartenders & 11.1 & 44.5 & 55.6 & 44.4 & \\
\hline Other & 25.0 & 0.0 & 25.0 & 75.0 & \\
\hline TOTAL & 22.4 & 32.8 & 55.2 & 44.8 & \\
\hline ALL HOTELS AND RESTAURANTS & 22.9 & 28.0 & 50.9 & 49.1 & \\
\hline
\end{tabular}


TABLE 8

Off-Season Change in Earnings Per Hour in Occupations

in the Tipping Zone

(Percentages)

\begin{tabular}{|c|c|c|c|c|c|c|c|c|c|}
\hline & \multicolumn{5}{|c|}{ Decline } & \multicolumn{4}{|c|}{ Increase } \\
\hline & Decline & Over 50 & $25-50$ & $10-24$ & $1-10$ & No Change & Increase & $1-10$ & Over 10 \\
\hline \multicolumn{10}{|l|}{ FOOD SER VICE } \\
\hline \multicolumn{10}{|l|}{ Waiters } \\
\hline Number & 14,986 & 4,449 & 3,278 & 5,854 & 1,405 & 3,044 & 3,980 & 1,873 & 2,107 \\
\hline Percentage & 68.1 & 20.2 & 14.9 & 26.6 & 6.4 & 13.8 & 18.7 & 8.5 & 9.6 \\
\hline \multicolumn{10}{|l|}{ Busboys } \\
\hline Number & 4,342 & 1,158 & 1,447 & 1,158 & 579 & 289 & 1,157 & 289 & 868 \\
\hline Percentage & 75.0 & 20.0 & 25.0 & 20.0 & 10.0 & 5.0 & 20.0 & 5.0 & 15.0 \\
\hline \multicolumn{10}{|l|}{ Bartenders } \\
\hline Number & 1,355 & 0 & 813 & 271 & 271 & 542 & 542 & 271 & 271 \\
\hline Percentage & 55.0 & 0 & 33.3 & 11.1 & 11.1 & 22.2 & 22.2 & 11.1 & 11.1 \\
\hline \multicolumn{10}{|c|}{ Food Service Sub-Total } \\
\hline Number & 20,683 & 5,607 & 5,538 & 7,283 & 2,255 & 3,875 & 5,679 & 2,433 & 3,246 \\
\hline Percentage & 68.4 & 18.5 & 18.3 & 24.1 & 7.5 & 12.8 & 18.8 & 8.0 & 10.7 \\
\hline \multicolumn{10}{|l|}{ NON-FOOD HOTEL } \\
\hline \multicolumn{10}{|l|}{ Bellhops } \\
\hline Number & 1,176 & 470 & 353 & 235 & 118 & 118 & 0 & 0 & 0 \\
\hline Percentage & 90.9 & 36.3 & 27.3 & 18.2 & 9.1 & 9.1 & 0 & 0 & 0 \\
\hline Bartenders & & - & & & & & & & \\
\hline Number & 762 & 0 & 254 & 254 & 254 & 254 & 507 & 507 & 0 \\
\hline Percentage & 50.0 & 0 & 16.7 & 16.7 & 16.7 & 16.7 & 33.3 & 33.3 & 0 \\
\hline \multicolumn{10}{|c|}{ Non-Food Hotel Sub-Total } \\
\hline Number & 1,938 & 470 & 607 & 489 & 372 & 372 & 507 & 507 & 0 \\
\hline Percentage & 68.8 & 16.7 & 21.5 & 17.4 & 13.2 & 13.2 & 18.0 & 18.0 & 0 \\
\hline \multicolumn{10}{|c|}{ All Occupations in Tipping Zone } \\
\hline Number & 22,621 & 6,077 & 6,145 & 7,772 & 2,627 & 4,247 & 6,186 & 2,940 & 3,246 \\
\hline Percentage & 68.4 & 18.4 & 18.6 & 23.5 & 7.9 & 12.8 & 18.7 & 8.9 & 9.8 \\
\hline
\end{tabular}


motels, where tips may not always be fully declared to the Internal Revenue Service. Rather than risk the possibility of a high non-response rate by asking for earnings information, we asked for the percentage change in weekly earnings between the season and the off-season. The problem with this approach is that it required some calculations on the part of respondents, and this may be the source of some error.

Hourly earnings differentials can in general be expected to occur in those occupations in the tipping zone; bellhops, bartenders, waiters, and busboys. By subtracting the reported percentage change in weekly hours worked from the reported percentage change in weekly wages plus tips for these occupations, the percentage change in average hourly earnings can be estimated. The results are given in Table 8 . They show that over two-thirds of the employees in the tipping zone experience a decline in earnings per hour. The percentage experiencing a decline is equivalent in the non-food hotel and food service occupations.

\section{INCORPORATING SEASONAL SHIFTS IN LABOR SUPPLY}

The descriptive analysis of the preceding sections showed a decline in the number of jobs in the tourist industry during the off-season, and declines in the hours worked and hourly earnings of those remaining employed. The conventional literature treats these features of seasonal occupations as undesirable $[2,9]$. However, there are important theoretical reasons for believing there may be seasonal fluctuations in the supply of labor.

Households perform two primary functions in the market economy: they purchase desired goods and services and supply labor to the market [1]. The constraints under which a household operates are its non-human (property) wealth and its time. For most of the households supplying labor in the occupations reported on here, non-human wealth is relatively small so that the primary constraint on household activities is time. Any household must make an allocation of its time between market and non-market activities. The reward for allocating time to the market is labor income (earnings) and the major uses of non-market time are housekeeping and child care, recreation, and investment in human capital such as schooling.

The value of time outside the market varies seasonally. The school system provides relatively cheap child care during the fall, winter, and spring, so that many households experience a seasonal increase in the market price of child care during the summer. Similarly, the production of recreation requires market goods in addition to household time. During the non-tourist season and with good weather, the value of devoting household time to recreation increases because fees for recreational amenities or simply the congestion of such amenities decreases in the off-season. Further, the risk of having a household recreational expedition damaged by bad weather may diminish. Thus, there are reasons to expect households to allocate less time to the market during the summer. This coincides with the off-season for the tourist industry in 
southeast Florida. Hence, at least some of the reduction in employment in the off-season can be expected to reflect a seasonal decline in the supply of labor.

An allowance for seasonal shifts in labor supply can be made using the following regression:

$$
\% \Delta \mathrm{H}_{\mathrm{i}}=-\mathrm{a}-\mathrm{b} \% \Delta \mathrm{W}_{\mathrm{i}}+\mathrm{u}_{\mathrm{i}}
$$

Where $\% \Delta \mathrm{H}_{\mathrm{i}}$ stands for the percentage change in hours during the off-season by employee $i$ and $\% \Delta \mathrm{W}_{\mathrm{i}}$ for the percentage change in the hourly wage; $\mathrm{u}$ is a stochastic disturbance. Figure 1 provides a basis for interpreting the equation.

In this figure $S_{s}$ and $S_{o}$ are the season and off-season labor supply, and $D_{s}$ and $D_{0}$ are the season and off-season demand, respectively. The point A represents the equilibrium market wage during the season $\left(\mathrm{W}_{\mathrm{A}}\right)$ and the equilibrium worked hours $\left(\mathrm{H}_{\mathrm{A}}\right)$.

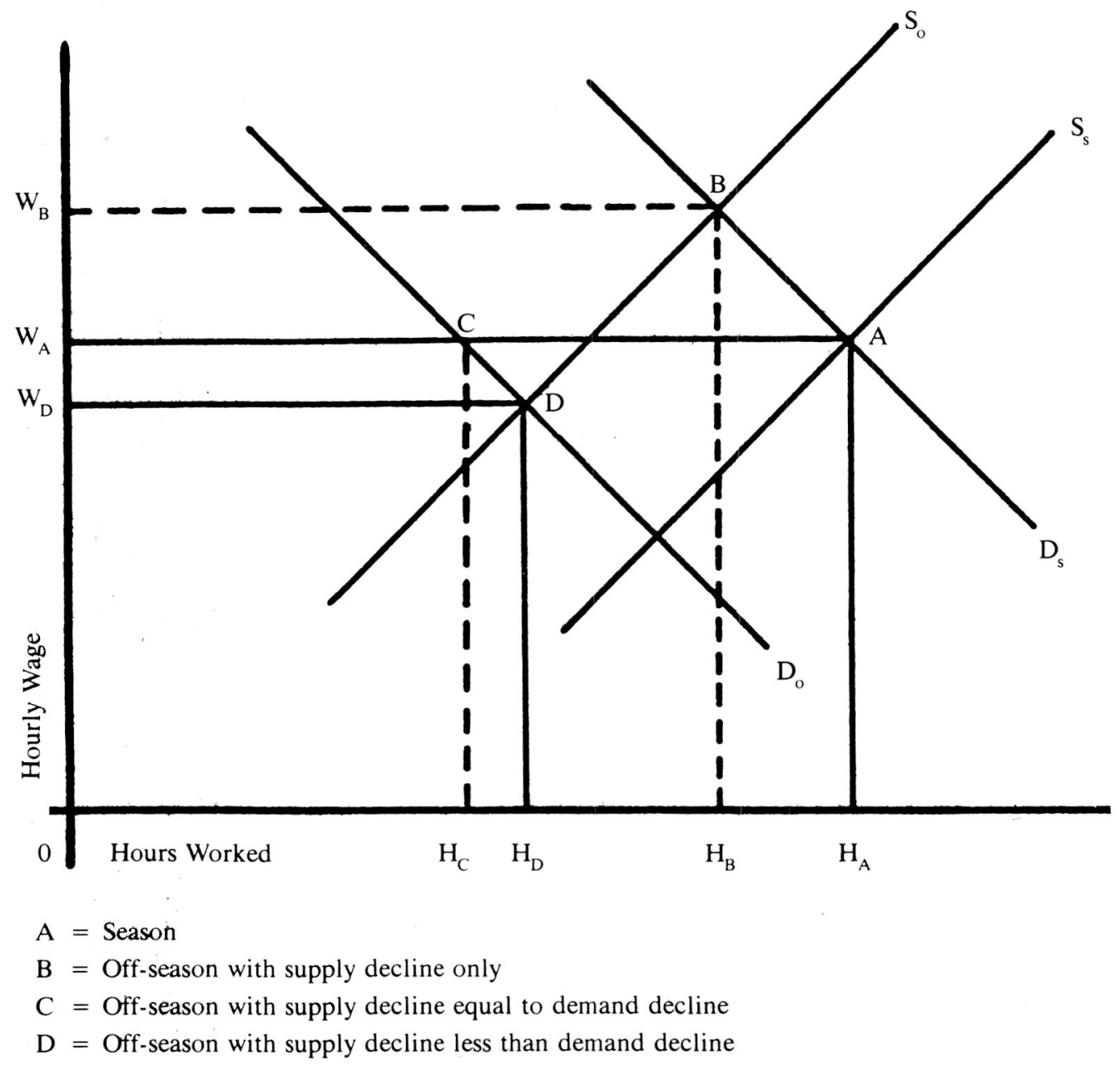

Figure 1. Seasonal and Non-seasonal Labor Market Equilibrium. 
In a nonseasonal industry, which cannot hire substantial numbers of students for adult employees, a decline in the supply of labor usually occurs during the summer months for the reasons mentioned earlier. Such a decline is shown as a movement of the supply curve from $S_{s}$ to $S_{0}$ with a given demand curve $\mathrm{D}_{\mathrm{s}}$. The result will be some decline in hours worked but an increase in earnings per hour worked. In many such industries workers receive pay for a number of hours in which they do not work (vacation) rather than an increase in their announced wage.

In Florida's tourist industry, a decline in the demand for labor occurs along with the supply decline. To the extent that students are hired to replace adult employees, the shift in $\mathrm{S}_{\mathrm{O}}$ will be reduced. The point $\mathrm{C}$ represents the offseason situation that would occur if the decline in the supply of labor matched the decline in the demand. The wage rate would remain the same as during the season $\left(\mathrm{W}_{\mathrm{A}}\right)$ but there would be a large decline in hours worked $\left(\mathrm{H}_{\mathrm{C}}<<\mathrm{H}_{\mathrm{A}}\right)$. If the supply of labor does not decline by the same amount as the demand, workers compete for the available work by driving wages below the seasonal level $\left(\mathrm{W}_{\mathrm{D}}<\mathrm{W}_{\mathrm{A}}\right)$ and hours worked $\mathrm{H}_{\mathrm{D}}$ do not decline to $\mathrm{H}_{\mathrm{C}}$.

The regression equation can now be interpreted in terms of Figure 1. The intercept $-\mathrm{a}$ is the percentage decline in hours worked during the off-season if wages were to remain the same $(\% \Delta \mathrm{W}=0)$. Thus, $-\mathrm{a}$ is $\left(\mathrm{H}_{\mathrm{C}}-\mathrm{H}_{\mathrm{A}}\right) / \mathrm{H}_{\mathrm{A}}$ expressed as a percentage. It measures the extent of the decline in the labor demand function during the off-season. By the algebra shown in footnote $1, b$ is the off-season elasticity of labor demand multiplied by $1-\mathrm{a}$. Thus, the regression coefficients can be used to estimate the elasticity of labor demanded by occupation in the off-season.

Table 9 presents the estimation of the equation for those employed in the off-season, and also for that sub-population employed in the same occupation during the off-season. The results conform to the expectation that the decline in the demand for labor is not matched by an equivalent decline in the supply of labor. For example, for those remaining in the same occupation in the offseason, the decline in demand for labor in the off-season is 12.7 percent. Because the supply of labor does not decrease to the same extent there is a decline in wage rates (11.9 percent) as workers bid for the available work. This decline in labor costs during the off-season stimulates the demand for labor. However, the off-season elasticity of the demand for labor is very low (.19) so that the earnings decline mitigates the decline in hours by only 2.1 percent. ${ }^{2}$ The result is an actual decline in hours worked of 10.6 percent (the decline in demand of 12.7 percent minus the stimulative effect of the wage decline).

These results enable the debate about the tourist industry providing an outlet for workers who would rather work less in the off-season, to be put in perspective. First, it is clear that because of seasonal fluctuations in the price of child care, and in the price of (outdoor) recreational activities, all industries experience some decline in the supply of labor they face during the summer. In the absence of any demand shift, the result would be an increase in 
Seasonal Shifts in Demand and Supply for Employees

in Hotels and Restaurants

\begin{tabular}{|c|c|c|c|c|c|c|c|}
\hline & $\begin{array}{l}\text { Mean Percent } \\
\text { Change in } \\
\text { Hourly } \\
\text { Earnings }^{\mathrm{a}}\end{array}$ & $\begin{array}{c}\text { Mean Percent } \\
\text { Change in } \\
\text { Hours }\end{array}$ & $\begin{array}{c}\text { Seasonal } \\
\text { Percent Change } \\
\text { in the Demand } \\
\text { for Labor }{ }^{c}\end{array}$ & $\begin{array}{c}\text { Mean induced } \\
\text { Percent Change } \\
\text { in Labor Demanded } \\
\text { Due to the } \\
\text { Earnings Change }^{\text {d }}\end{array}$ & $\begin{array}{l}\text { Elasticity } \\
\text { of } \\
\text { Labor } \\
\text { Demand }^{e}\end{array}$ & $R^{2^{f}}$ & $F^{f}$ \\
\hline $\begin{array}{l}\text { Those remaining } \\
\text { employed in the off- } \\
\text { season }\end{array}$ & -12.2 & -7.9 & -12.3 & 4.4 & .41 & .20 & 16028.8 \\
\hline $\begin{array}{l}\text { Those remaining in the } \\
\text { same occupation in the } \\
\text { off-season }\end{array}$ & -11.9 & -10.6 & -12.7 & 2.1 & .19 & .10 & 6092.5 \\
\hline
\end{tabular}

"In the notation of the regression equation this is the mean of $\% \Delta \mathrm{W}=\overline{\% \Delta \mathrm{W}}$.

h In the notation of the regression equation this is the mean of $\% \Delta \mathrm{H}=\overline{\% \Delta \mathrm{H}}$

In the notation of the regression equation this is $-\mathrm{a}$.

"This is column 3 minus column 2.

"In the notation of the regression equation this is $b /(1-a)$. It is the elasticity of labor demand at point $C$ in Figure 1 .

${ }^{\mathrm{I}}$ The $\mathrm{R}^{2}$ and $\mathrm{F}$ statistics are seriously distorted by the weighting procedure applied to the sample. They are merely suggestive. 
earnings per hour worked. The decline in the demand for labor by the tourist industry during the off-season prevents workers from obtaining this earnings per hour increase. Furthermore, the decline in labor demand actually exceeds the decline in labor supply so that the typical employee experiences a decline in the wage rate. Thus, the seasonality of tourism has an adverse impact on many individuals employed in the industry, and a traditional compensating differential can be expected to be needed. The size of this differential would be an interesting subject for further study.

The adverse impact arises in almost all the occupations (Table 10). Managers and cooks are the exceptions. The former experience little decline in labor demand, since managers are needed both in the season and the offseason. They are therefore similar to employees of non-seasonal industries. Cooks may be in a similar situation, but it is noteworthy that the statistical relationship reported in the table is insignificant. Bartenders have a somewhat less inelastic demand than the other occupations which enables them to avoid as large a loss in earnings per hour as the other employees in the tipping zone.

\section{CONCLUSIONS AND IMPLICATIONS}

Although tourist expenditures yield benefits to the residents of a region by providing job opportunities, the jobs are usually subject to seasonal fluctuations in labor demand. In the southeast Florida area, a region with a high dependence on tourism, employment in the front line tourist industries (hotels and restaurants) declines very substantially in the off-season (summer). This decline is large even when seasonal declines in the supply of labor are taken into account.

The seasonal declines in employment and hours worked are accompanied by substantial declines in hourly earnings, particularly in the tipping zone. This reflects the relatively low elasticity of labor demand facing most of the occupations in hotels and restaurants. Because of the strong personal service component of such occupations, the potential for substituting labor for other inputs is limited even when labor costs are reduced. Thus, hourly earnings drop very substantially in the off-season without having a significant ameliorating effect on the decline in employment and hours worked.

These results suggest that public policymakers should consider the impact of their expenditures for promoting and developing tourism on the seasonal nature of the industry. Any significant increase in the output of the industry during the season should be accompanied by policies to expand output during the off-season, or to provide alternative job opportunities in other industries during that period. Specifically, in a region like Florida, public expenditures ought to be used to develop the off-season (summer) tourist industry, e.g., tourists from South America, and manpower policies ought to be directed toward expanding the range of job opportunities available to tourist employees in the off-season. 
TABLE 10

Seasonal Shifts in Demand and Supply for Occupations in

Hotels and Restaurants

\begin{tabular}{|c|c|c|c|c|c|c|c|}
\hline & $\begin{array}{l}\text { Mean Percent } \\
\text { Change in } \\
\text { Hourly } \\
\text { Earnings }^{\mathrm{a}}\end{array}$ & $\begin{array}{c}\text { Mean Percent } \\
\text { Change in } \\
\text { Hours }^{b}\end{array}$ & $\begin{array}{c}\text { Seasonal } \\
\text { Percent Change } \\
\text { in the Demand } \\
\text { for Labor }{ }^{c}\end{array}$ & $\begin{array}{c}\text { Mean induced } \\
\text { Percent Change } \\
\text { in Labor Demanded } \\
\text { Due to the } \\
\text { Earnings Change }^{\mathrm{d}}\end{array}$ & $\begin{array}{l}\text { Elasticity } \\
\text { of } \\
\text { Labor } \\
\text { Demand }^{\mathrm{e}}\end{array}$ & $R^{2^{f}}$ & $F^{f}$ \\
\hline \multicolumn{8}{|l|}{ Hotels } \\
\hline Clerical & -2.8 & -6.4 & -6.6 & 0.2 & 0.07 & .01 & 24.2 \\
\hline Bellhops & -34.1 & -8.6 & -12.5 & 3.9 & 0.13 & .04 & 51.7 \\
\hline Maids & -11.3 & -15.3 & -16.4 & 1.1 & 0.11 & .04 & 217.3 \\
\hline Parking Attendants & -21.9 & -15.7 & -17.9 & 2.2 & 0.12 & .05 & 23.9 \\
\hline Managers & 2.9 & -16.9 & -16.2 & -0.7 & 0.29 & .31 & 742.7 \\
\hline Bartenders & -8.2 & -19.8 & -23.6 & 3.8 & 0.62 & .16 & 281.4 \\
\hline Other & insufficient cases & & & & & & \\
\hline \multicolumn{8}{|l|}{ Restaurants } \\
\hline Cashier & -1.0 & -6.3 & -6.5 & 0.2 & 0.90 & .22 & 858.8 \\
\hline Cleaners & insufficient cases & & & & & & \\
\hline Parking Attendants & insufficient cases & & & & & & \\
\hline Bartenders & -9.3 & -7.4 & -11.1 & 3.7 & 0.45 & .37 & 1424.4 \\
\hline Waiters & -21.4 & -13.6 & -18.3 & 4.7 & 0.27 & .14 & 3540.0 \\
\hline Busboys & -18.3 & -2.0 & -6.9 & 4.9 & 0.29 & .24 & 1783.4 \\
\hline Cooks & 3.7 & -4.4 & -4.4 & 0.0 & 0.01 & .00 & 3.5 \\
\hline Kitchen Help & insufficient cases & & & & & & \\
\hline Entertainers & insufficient cases & & & & & & \\
\hline
\end{tabular}

Notes: Refer to Table 9 


\section{FOOTNOTES}

1. If we assume that the labor market is at equilibrium in the two seasons (points $\mathrm{A}$ and D), then

$$
\begin{aligned}
& \% \Delta \mathrm{H}=\left(\mathrm{H}_{\mathrm{D}}-\mathrm{H}_{\mathrm{A}}\right) / \mathrm{H}_{\mathrm{A}} \\
& \% \Delta \mathrm{W}=\left(\mathrm{W}_{\mathrm{D}}-\mathrm{W}_{\mathrm{A}}\right) / \mathrm{W}_{\mathrm{A}}
\end{aligned}
$$

From the figure it is also clear that

$$
-\mathrm{a}=\left(\mathrm{H}_{\mathrm{C}}-\mathrm{H}_{\mathrm{A}}\right) / \mathrm{H}_{\mathrm{A}}
$$

since this is the decline in hours that would occur if off-season earnings per hour remained at the season rate. Thus, the equation can be written in terms of the figure as

$$
\left(\mathrm{H}_{\mathrm{D}}-\mathrm{H}_{\mathrm{A}}\right) / \mathrm{H}_{\mathrm{A}}=
$$

$$
\left(\mathrm{H}_{\mathrm{C}}-\mathrm{H}_{\mathrm{A}}\right) / \mathrm{H}_{\mathrm{A}}-\mathrm{b}\left(\mathrm{W}_{\mathrm{D}}-\mathrm{W}_{\mathrm{A}}\right) / \mathrm{W}_{\mathrm{A}}
$$

To show that $\mathrm{b} /(1-\mathrm{a})$ can be interpreted as a crude measure of the elasticity of demand, multiply through by $\mathrm{H}_{A}$ and cancel terms to yield

$$
\mathrm{H}_{\mathrm{D}}-\mathrm{H}_{\mathrm{C}}=-\mathrm{b}\left[\left(\mathrm{W}_{\mathrm{D}}-\mathrm{W}_{\mathrm{A}}\right) / \mathrm{W}_{\mathrm{A}}\right] \mathrm{H}_{\mathrm{A}}
$$

Dividing both sides by $-\mathrm{H}_{C}$ we obtain

$$
\% \Delta \mathrm{H}^{*}=\left(\mathrm{H}_{\mathrm{C}}-\mathrm{H}_{\mathrm{D}}\right) / \mathrm{H}_{\mathrm{C}}=
$$$$
\left(\mathrm{H}_{\mathrm{A}} / \mathrm{H}_{\mathrm{C}}\right) \mathrm{b} \% \Delta \mathrm{W}=(1-\mathrm{a})^{-1} \mathrm{~b} \% \Delta \mathrm{W}
$$

Where the asterisk notes that the $\% \Delta \mathrm{H}$ occurs along the demand curve $\mathrm{D}_{\text {。 }}$.

Hence

$$
\% \Delta H^{*} / \% \Delta \mathrm{W}=\mathrm{b} /(1-\mathrm{a})
$$

and this is the response of labor demand to the earnings per hour decline during the offseason. It is a crude measure of elasticity of demand at point $\mathrm{C}$ in Figure 1.

2. In the notation of the equation this induced increase in labor demanded is $-\mathrm{b} \% \Delta$ $W /(1-a)$. This figure is not the same as column 4 (column 3 minus column 2) of Tables 9 and 10 because the formula yields results with the off-season demand as the base $\left(\mathrm{H}_{\mathrm{C}}\right.$ in Figure 1) rather than the season equilibrium $\left(\mathrm{H}_{\mathrm{A}}\right)$. Column 4 gives the induced increase in labor demanded in the common base $\left(\mathrm{H}_{\mathrm{A}}\right)$.

\section{REFERENCES}

1. Becker, Gary S., "A Theory of the Allocation of Time" Economic Journal Vol. 75 (September 1965), pp. 493-517.

2. Chiswick, Barry R., Income Inequality: Regional Analyses Within a Human Capital Framework, New York: National Bureau of Economic Research, 1974.

3. Doering, Thomas R. "A Reexamination of the Relative Importance of Tourism to State Economies," Journal of Travel Research, Vol. XV, No. 1 (Summer 1976), pp. 13-17.

4. Florida Department of Business Regulation, Division of Hotels and Restaurants. "Computer Listing of Hotels, Motels, and Restaurants," October 24, 1977.

5. Florida Department of Commerce, Division of Employment Security, Florida Labor Market Trends, Miami, 1973-77.

6. Florida Department of Commerce, Division of Tourism, Florida Tourist Study 1978.

7. Hauser, Robert M. and David L. Featherman, The Process of Stratification: Trends and Analysis, New York: Academic Press 1977.

8. Schultz, Ronald R. and William B. Stronge, The Social and Economic Effects of the Florida Tourist Industry Report to the Office of Manpower Planning, Florida Department of Community Affairs, Tallahassee, Fla. 1978.

9. U.S. Department of Labor, Report of the Chicago Construction Coordinating Committee, Washington D.C.: Superintendent of Documents, 1977. 